\title{
The Influences of the Usage of Marketing Communication Tools on Innovations of the Functional Areas of Businesses: Perspectives for the Mining Industry
}

\author{
Mehmet CíVELEK ${ }^{1 *}$, Aleksandr KLJUČNIKKOV ${ }^{2}$, Lubomír KMECO ${ }^{3}$ and \\ Iveta HAMARNEH ${ }^{4}$
}

Authors' affiliations and addresses:

${ }^{1}$ Institute of Entrepreneurship and Marketing,

University of Entrepreneurship and Law,

Michálkovická 1810/181, 71000 Ostrava-Slezská

Ostrava, Czech Republic

e-mail: m_civelek@windowslive.com

${ }^{2}$ Institute of Entrepreneurship and Marketing, University of Entrepreneurship and Law, Michálkovická 1810/181, 71000 Ostrava-Slezská Ostrava, Czech Republic

e-mail: kliuchnikov@gmail.com

${ }^{3}$ Department of Tourism, University College of Business in Prague, Spálená 76, 11000 Nové

Město\ Prague, Czech Republic

e-mail:kmeco@vso-praha.eu

${ }^{4}$ Department of Tourism Economy, University College of Business in Prague, Spálená 76, 110 00 Nové Město\Prague\Czech Republic e-mail: hamarneh@vso-praha.eu

*Correspondence:

Mehmet Civelek, Institute of Entrepreneurship and Marketing, University of Entrepreneurship and Law, Michálkovická 1810/181, 71000 Ostrava-Slezská Ostrava, Czech Republic tel.: +420773873403

e-mail: m_civelek@windowslive.com:

How to cite this article:

Civelek, M., Ključnikov, A., Kmeco, L'. and Hamarneh, I. (2021). The Influences of the Usage of Marketing Communication Tools on Innovations of the Functional Areas of Businesses: Perspectives for the Mining Industry. Acta Montanistica Slovaca. Volume 26 (4) 685697

DOI:

https://doi.org/10.46544/AMS.v26i4.08

\begin{abstract}
The usage of marketing communication tools has always been a potent strategy for businesses to increase their performances and profitability in all sectors, including the mining industry. However, there is a lack of studies concerning the usage of those channels and their impacts on the innovativeness of functional areas of businesses. Since innovativeness is a crucial ability for enterprises to survive, focusing on this competency in functional areas businesses might fulfill this research gap. In this regard, this paper purposes of examining the influences of the usage of marketing communication tools on innovations of those areas of businesses. In line with this purpose, the researchers have created an online interned mediated questionnaire and directed it to the randomly selected 812 SMEs from Slovakia. To explore the effects of those tools on functional areas of businesses, the researchers employ the Ordinal Logistic Regression Test. The results from the analyses vindicate the fact that when SMEs apply traditional and technologyenabled marketing communication tools, they become more innovative in some activities, namely, marketing, logistics, finance, human resources, processes, and management, except suppliercustomer relationships. While traditional marketing communication tools positively impact businesses' innovations regarding a suppliercustomer relationship, the usage of technology-enabled marketing communication tools does not create significant effects on innovations in this relationship. The reason for that might be related to the location of SMEs, the regional income gap in countries, workload and competencies of workers and the Covid-19 pandemic. The research also presents some policy implications to cope with the negative outcomes of the above-mentioned reasons. This issue is of great importance also for companies operating in the mining industry. Thus, the findings represent a valuable platform of knowledge for various business areas, such as mining.
\end{abstract}

\section{Keywords}

Marketing communication tools, digital marketing, technologyenabled, traditional, SMEs, Slovakia, innovation, logistics, finance, human resources, process, management, supplier-customer relationships, mining industry. 


\section{Introduction}

SMEs do not only provide benefits for the creation of new value-added products but also have key roles in labour productivity (Belas et al., 2020). Moreover, their flexible structure enables them to supply innovative goods and services for their customers. On the other hand, SMEs usually encounter some obstacles due to having a lack of investments and financial sources or legislative and administrative difficulties (Appiah et al., 2019; Gavurova et al., 2020a). Therefore, SMEs' usage of marketing communication tools has vital importance since those innovative channels increase their marketing and financial performance. In this regard, this paper aims to analyze the impacts of the usage of traditional and technology enabled (modern) marketing tools on innovations in the functional areas of businesses. The functional areas of businesses that this paper considers are marketing, logistics, finance, human resources, processes, management and supplier-customer relationships.

Marketing communication tools are also determinant factors for success (Zaušková \& Grib, 2014), performance (Kallier, 2017) and strategy-making processes of firms (Kizim et al., 2019). Regarding the types of marketing communication tools, they are differently categorized by various researchers (Cant \& Wiid, 2016; Amirkhanpour et al., 2014; Kallier, 2017). In this research, those tools are categorized as traditional and technology enabled marketing tools depending on their non-digital, offline or digital online functions, as other studies have suggested (Cant \& Wiid, 2016; Kallier, 2017). Since PR/Public relations, sales promotion, direct marketing, personal selling/face to face communication, sponsoring, exhibitions/trade shows, and advertising in the traditional media (print etc.) are not online ways of marketing communication. Thus, this paper classifies those tools as traditional marketing communication tools in line with the above-mentioned researchers' categorizations. Concerning technology enabled marketing tools, they are based on online and digital activities such as online marketing/internet, advertising in social media, content marketing/social media, mobile marketing (SMS, MMS...), chatbot (Facebook-MSN), viral marketing, and e-WOM. Therefore, this research investigates modern marketing communication tools by using those channels as other studies categorize them (Taiminen \& Karjaluoto, 2015; Kallier, 2017; Amirkhanpour et al., 2014).

The increases in the number of traditional media channels have made those traditional marketing communication platforms to become an intense tool in the marketing activities of businesses (Cant \& Wiid, 2016). Moreover, since most traditional marketing tools provide close interactions, they are still convenient and popular even in the digital era (Bobalo, 2018). Corresponding to technology enabled marketing communication tools, social media is the most common platform. Social media create many opportunities for SMEs to hit their targets regarding marketing their products and services and increase their brand awareness (Wardati \& Mahendrawathi, 2019; Jokonya \& Mugisha, 2019; Taiminen \& Karjaluoto, 2015). Therefore, many businesses employ social media experts in their organizational structure to work in their marketing department (Indrupati \& Henari, 2012).

The usage of those online channels has become widespread, especially during the Covid-19 pandemic. This is because rapid increases in the spreading speed of Covid-19 and the nonexistence of any vaccine have made policymakers apply radical changes such as requiring workers to stay their home to do their work there (Jakhiya et al., 2020; Kakushadze \& Liew, 2020), and schools and universities to do education via online platforms to reduce interactions among people and to keep social distance among them (Pantano et al., 2020; Jakhiya et al., 2020; Kakushadze \& Liew, 2020). Thus, many restrictions have come into existence regarding people mobility. Millions of employees have been negatively influenced by Covid-19 since they have stayed at their homes with unpaid leave from their job (Korzeb \& Niedziółka, 2020; Nicola et al., 2020). Sports competitions such as the Olympic Games and European Football Championship have been postponed to 2021 (Nicola et al., 2020).

Regarding innovation activities of firms, they affect all functional and organizational areas of businesses, including finance, human resources, management (Falcones \& Castilla, 2020), marketing (Kallier, 2017), logistics (Kizim et al., 2019; Ibrahim et al., 2019), process (Ahmad \& Salleh, 2019), and supplier-customer relationship (Turan \& Kara, 2018; Calefato et al., 2015; Amoah et al., 2021). Since the changes in marketing communication tools are indicators of firms' innovative posture, the influences of marketing communication tools on functional areas of businesses might be noteworthy to examine. In this regard, the research questions might arise as follows: "Do traditional and technology enabled marketing communication tools positively affect the functional areas of businesses?"

Although many studies analyze the impacts of marketing communication tools on functional areas of businesses, they only focus only one of those areas, such as marketing (Pisicchio \& Toaldo, 2020), logistics (Mabrouk, 2020; Milichovský, 2017) finance (Seiler et al., 2020), human resources (Cabiddu et al., 2020), processes (Ahmad \& Salleh, 2019), management (Ližbetinová et al., 2019), and supplier-customer relationship (Turan \& Kara, 2018). Different from those studies, this paper looks from a widened perspective to all of those various functional areas of businesses and investigate the impacts of marketing communication tools on those areas. Moreover, those above-mentioned studies do not make categorization on the marketing communication tools and do not analyze the impacts of different categories of marketing communication tools on business functional and operational areas. But, this paper separately analyzes the effects of both traditional and modern 
marketing tools on the functional areas of businesses. For these reasons, this comprehensive study creates a value addition and fulfils this research gap. In addition, to do that, this research analyzes 812 SMEs from one of the European countries, namely, Slovakia.

The rest of the paper is organized as follows: Material and Methods section presents the empirical results of previous studies to set the research hypotheses. Then it enlightens the methodological approaches that the researchers follow and reveals the detail about the data and data collection process. The results section outlines the result of this paper, while the Discussion section provides some potential reasons for the results and professes some policy implications. Finally, in Conclusion, the researchers summarize the main points of the paper and present the limitations of the study with directives for future research.

\section{Material}

\section{Material and Methods}

Innovations in marketing do not only include changes in packaging, promoting, pricing and design of products or services but also include changes in marketing strategies (Falcones \& Castilla, 2020), the usage of marketing communication systems (Laužikas \& Miliūtè, 2020) and the creations in new methods in marketing (Amoah \& Jibril, 2020). In this regard, the effective usage of marketing communication tools by SMEs has vital importance for innovations in marketing activities (Kotler \& Keller, 2009; Laužikas \& Miliūtè, 2020). Moreover, marketing communication tools have positive impacts on the performance of SMEs regarding marketing (Porcu et al., 2019; Pisicchio \& Toaldo, 2020). Similarly, as a technology-based marketing communication tool, social media also has positive impacts on the advertising activities of SMEs (Pisicchio \& Toaldo, 2020). This is because the usage of social media platforms by SMEs also increases their innovativeness and enables them to make innovations in advertising and communication that are beneficial for the marketing activities of SMEs (Amoah \& Jibril, 2020). Considering the traditional marketing tools, they are components of integrated marketing communication, and they help firms to increase their innovative actions in communications and marketing (Gabrielli \& Balboni, 2015; Pisicchio \& Toaldo, 2020). Those above-mentioned studies make this paper create the following hypotheses:

H1a: The usage of traditional marketing communication tools positively affects innovations in marketing.

$\mathrm{H} 1 \mathrm{~b}$ : The usage of technology-based marketing communication tools positively affects innovations in marketing.

Regarding innovations in logistics and marketing communication tools, many studies confirm the relationship between them since those communication tools affect some processes in logistics, such as supply chain reverse logistics (Mabrouk, 2020; Milichovský, 2017). For instance, when businesses try to increase demand for their products by their marketing tools, their efficiency in logistics also help those businesses to fulfil the demands of their customers (Kizim et al., 2019). Moreover, the usage of online marketing tools makes businesses to shorten their supply chain processes since they can directly contact their customers (Chakraborty et al., 2016; Cabiddu et al., 2020). Therefore, changes in technology-enabled marketing tools directly make positive contributions to the logistics activities of firms. When businesses make advertisements or campaigns by traditional media channels, they also make their customers aware of their new products or services to repair the bought products (Milichovský, 2017). Thus, to fulfil the increased demands of their customers that are generated by marketing communication tools, businesses implement innovative strategies for their logistic operations. In this regard, other hypotheses might be set as follows:

H2a: The usage of traditional marketing communication tools positively affects innovations in logistics.

$\mathrm{H} 2 \mathrm{~b}$ : The usage of technology-enabled marketing communication tools positively affects innovations in logistics.

The positive impacts of the usage of marketing communication channels by SMEs on their financial performance have also been highlighted by some studies (Seiler et al., 2020; Amoah et al., 2021; Zaušková \& Grib, 2014). But except for increasing financial performance, marketing communication tools also do businesses to find new methods for financial transactions. For instance, marketing activities need to be directly associated with financial purposes of businesses, including budgeting (Laužikas \& Miliūtè, 2020) and financial analysis (Petersen et al., 2009; Laužikas \& Miliūtè, 2020). By using those channels and implementing artificial intelligence, machine learning and blockchain technology, companies become able to know the details about their prospective or existing customers, such as their age, gender, nationality and their income (Ratnakaram et al., 2021). By doing so, they might provide better patterns for their customers' payments, including instalments by credit cards. By analyzing insurance products, Ratnakaram et al. (2021) state that when doing marketing for those products, companies not only provide financial advantages for their customers but also give information about the date of renewal or maturity and processes for the claims. All those actions that are related to financial issues are outcomes of innovative actions. Thus, the usage of those communication tools has stimulated the innovative posture of firms regarding financial operations. In this regard, the following hypotheses can be generated as follows:

H3a: The usage of traditional marketing communication tools positively affects innovations in finance. 
H3b: The usage of technology-enabled marketing communication tools positively affects innovations in finance.

Considering the effective usage of marketing communication tools, human resources also have been one of the major concerns of SMEs. The reason for that is the lack of experience, awareness and abilities of workers. To overcome those issues, companies provide some training and educational activities that make the abilities of workers increase (Cabiddu et al., 2020; Martinez \& Dolores, 2018), so the human capital. Human capital also includes some actions of workers, such as creating new ideas that cause innovative solutions (Zontek, 2016; Falcones \& Castilla, 2020). Thus, the usage of marketing communication reveals some human resource activities that are based on innovative changes. This is because changes in technologies also differentiate the usage of marketing communication tools. In this regard, firms need to provide new training and life-long learning activities, including the usage of new communication tools (Laužikas \& Miliūte, 2020). The above-mentioned arguments make this paper create other research hypotheses as follows:

H4a: The usage of traditional marketing communication tools positively affects innovations in human resources.

H4b: The usage of technology-enabled marketing communication tools positively affects innovations in human resources.

Innovations in processes are complicated since it consists of many different stages from production to distribution of products and services (Falcones \& Castilla, 2020), such as planning, development and controlling (Zaušková et al., 2015; Leopold, 2019). Thus, this process requires an efficient decision-making stage (Falcones \& Castilla, 2020) that is stimulated by communication between all players of innovative actions (Wahyuni \& Aprilia, 2019). For instance, although firms use social media platforms for their marketing purposes, workers can also use Instagram, Whatsapp or other platforms to have close interactions. Therefore, when implementing efficient marketing communication tools into firm organizational processes, marketing (Ahmad \& Salleh, 2019; Pisicchio \& Toaldo, 2020), sales and operational performance of firms increases (Wardati \& Mahendrawathi, 2019; Seiler et al., 2020; Amoah et al., 2021). Similarly, personal selling and sales promotion that are methods in traditional marketing communication, increase the performance of firms regarding the eco-innovation process (Zaušková et al., 2015). Therefore, innovation in processes is highly related to the use of marketing communication tools (Falcones \& Castilla, 2020). For those reasons, other hypotheses regarding innovation in processes might be presented as follow:

H5a: The usage of traditional marketing communication tools positively affects innovations in processes.

$\mathrm{H} 5 \mathrm{~b}$ : The usage of technology-enabled marketing communication tools positively affects innovations in processes.

Corresponding to innovations in management of businesses, marketing communication tools also make positive contributions on it (Hultman et al., 2011; Ližbetinová et al., 2019; Laužikas \& Miliūtè, 2020). The changes that marketing communication tools create in business operations require alterations in existing responsibilities, status and duties of workers in a firm. Thus, it affects the managing process of businesses by implementing new strategies and methods. For instance, in parallel with the usage of new traditional and technology enabled marketing tools, organizations can increase their innovative capabilities and fund more R\&D projects that can cause changes in managerial roles and organizational structure. By having a new management approach, firms can also motivate their workers to share their experiences information about tasks of their operations by creating a network (Leopold, 2019). By doing so, workers become more likely to propose innovative solutions for the demands of their customers (Lee, 2017; Ližbetinová et al., 2019). In line with the above-mentioned evidence, other research hypotheses might arise as indicated below:

H6a: The usage of traditional marketing communication tools positively affects innovations in management.

H6b: The usage of technology-enabled marketing communication tools positively affects innovations in management.

Concerning supplier and customer relationships and the usage of marketing communication tools, it can be stated that those tools enable businesses to have a close relationship with their suppliers and customers (Pisicchio \& Toaldo, 2020; Turan \& Kara, 2018; Calefato et al., 2015; Amoah et al., 2021). By using those communication channels, firms offer products and services that are demanded by customers (Zaušková et al., 2015) and satisfy the needs of consumers (Turan \& Kara, 2018). For instance, customers are able to send their comments via social media platforms. Thus, businesses can receive fed backs from them (Calefato et al., 2015). On the other hand, firms can also send some signals that include information about their products or services via those platforms (Pisicchio \& Toaldo, 2020). Regarding traditional marketing communication tools, both customers and suppliers can see some brochures or advertisements of firms since those channels are publicly visible for everyone. For example, firms can indicate some photos on those brochures that signal the quality and innovative posture of companies (Calefato et al., 2015). For these reasons, the interactions between supplier-customer and businesses might become closer and positively affect the relationship between those sides. The empirical results of the above-mentioned studies enable this research to set the last research hypotheses as follows: 
H7a: The usage of traditional marketing communication tools positively affects innovations in a suppliercustomer relationship.

H7b: The usage of technology-enabled marketing communication tools positively affects innovations in a supplier-customer relationship.

\section{Methods}

This paper aims to investigate and examine the impacts of the usage of traditional and technology enabled marketing tools by SMEs on the functional areas of businesses, such as marketing, logistics, finance, human resources, processes, management, and supplier-customer relationship. In parallel with this aim, an online internet-mediated questionnaire is generated by the researchers and directed to prospective respondents to collect the research data. Those respondents were selected by employing a random sampling method. The data collection was carried out in January 2021. The research sample includes 812 SMEs that are located in the Slovak Republic.

The researchers have directed the following survey question to investigate the usage of traditional and technology enabled marketing communication tools by SMEs that are the independent variables of all research models: "In which communication tool of marketing communication is innovation most evident in your business?". The researchers have provided some options for the answer of this question regarding traditional marketing communication tools as follows: PR/Public relations, sales promotion, direct marketing, personal selling/face to face communication, sponsoring, exhibitions/trade shows and advertising in the traditional media (print....). Moreover, the researchers have also presented answer choices for technology enabled marketing communication tools as follows "online marketing/internet, advertising social media, content marketing/social media, mobile marketing (SMS, MMS...), viral marketing, WOM, a chatbot (Facebook-MSN)". To scale each of the responses of the survey participants, each of those channels ranked by a five-point Likert scale from 1 - least significant to 5 - most significant.

Corresponding with the evaluation of the dependent variables, the researchers have asked the following survey question to the survey participants: "In which area do you think your business is innovative?". Those areas are presented under this survey question as follows: Marketing, Logistics, Finance, Human resources, Processes, Management and Supplier-customer relationship. Each of these areas is a dependent variable of the research models that are presented below. Similar to the measurements of independent variables, the researchers also scaled the responses of survey participants by five points Likert Scale from 1 - least significant to 5 -most significant regarding the evaluation of the dependent variables. Since dependent variables are ordinal and independent variables are categorical and ranked, the researchers run Ordinal Logistics Regression Tests by SPSS Statistical Program to analyze the impacts of independent variables on dependent variables. Although there are five categories of ordinal regression, since the dependent variables in this research are more likely to have higher volumes, the researchers consider logit ordinal logistic regression function. In this regard, the research models related to logit ordinal logistic regression models might be presented as follows:

$$
\operatorname{Logit}(P(Y \leq j))=\beta_{j 0}+\beta_{j 1} X_{1}+\beta_{j 2} X_{2}
$$

$Y=$ Ordinal outcome (Marketing for Model-1, Logistics for Model-2, Finance for Model-3, Human resources for Model-4, Processes for Model-5, Management for Model-6, Supplier-customer relationship for Model-7)

$j=$ categories

$X_{1}$ - Independent variable (usage of traditional marketing communication tools)

$X_{2}$ - Independent variable (usage of technology enabled marketing communication tools)

$B_{1}-$ Regression coefficients

$\beta_{0}-$ Constant or intercept term.

$P$ - predictor

\begin{tabular}{l|ccc|cc|ccccc}
\multicolumn{8}{c}{ Tab. 1. Analyzing assumption of Ordinal Logistic Regression Models } \\
\hline Assumptions & \multicolumn{3}{|c|}{ Model fitting } & \multicolumn{2}{c}{$\begin{array}{c}\text { Goodness of fit } \\
\text { Pseudo R-square }\end{array}$} & \multicolumn{4}{c}{ Test of parallel lines } \\
\hline Models & $\begin{array}{c}-2 \text { Log } \\
\text { likelihood }\end{array}$ & $\begin{array}{c}\text { Chi- } \\
\text { Square }\end{array}$ & df & Sig & Cox \& Snell & Nagelkerke & $\begin{array}{c}-2 \text { Log } \\
\text { likelihood }\end{array}$ & $\begin{array}{c}\text { Chi- } \\
\text { Square }\end{array}$ & df & Sig \\
\hline Model 1 & 1503.889 & 465.930 & 2 & $\mathbf{0 . 0 0 0}$ & 0.437 & 0.458 & 1499.665 & 4.225 & 6 & 0.646 \\
Model 2 & 1555.390 & 306.416 & 2 & $\mathbf{0 . 0 0 0}$ & 0.315 & 0.332 & 1538.258 & 17.133 & 6 & 0.056 \\
Model 3 & 1549.431 & 362.504 & 2 & $\mathbf{0 . 0 0 0}$ & 0.360 & 0.378 & 1540.296 & 9.135 & 6 & 0.166 \\
Model 4 & 1565.959 & 386.088 & 2 & $\mathbf{0 . 0 0 0}$ & 0.379 & 0.397 & 1555.590 & 10.369 & 6 & 0.110
\end{tabular}




\begin{tabular}{l|cccc|cc|cccc} 
Model 5 & 1605.783 & 337.174 & 2 & $\mathbf{0 . 0 0 0}$ & 0.340 & 0.356 & 1588.912 & 16.871 & 6 & 0.062 \\
Model 6 & 1520.673 & 432.525 & 2 & $\mathbf{0 . 0 0 0}$ & 0.413 & 0.434 & 1508.120 & 12.553 & 6 & 0.051 \\
Model 7 & 1582.760 & 395.603 & 2 & $\mathbf{0 . 0 0 0}$ & 0.386 & 0.404 & 1573.395 & 9.365 & 6 & 0.121 \\
\hline \multicolumn{1}{c}{ Source: Own processing. }
\end{tabular}

Tab. 1. depicts the statistics of model fitting, Pseudo R-square and test of parallel lines. Regarding model fitting, -2 Log likelihood and Chi-square test are presented to indicate whether there is a significant improvement in overall models' fit or not. According to table, overall models are statistically significant at $5 \%$ significance level. Thus, there is a significant improvement in fit of the final models over the null models and the models fit with the data (Model 1=, $\chi^{2}(2)=465.930$, Sig, $p<0.05$; Model 2= $\chi^{2}(2)=306.416$, Sig, $p<0.05$; Model 3= $\chi^{2}(2)=362.504$, Sig, $p<0.05 ;$ Model $4=\chi^{2}(2)=386.088$, Sig, $p<0.05$; Model $5=\chi^{2}(2)=337.174$, Sig, $p<$ 0.05 ; Model $=\chi^{2}(2)=432.526$, Sig, $p<0.05$; Model $7=\chi^{2}(2)=395.603$, Sig, $p<0.05$ ). Considering Pseudo Rsquare that is an indicator of Goodness of fit, includes Cox \& Snell and Nagelkerke Statistics. In this regard, it can be elucidated that Model 1 explains $45.8 \%$ of the variability in the dependent variable of this model, namely, marketing innovation. Similarly, other models also explain $33.2 \%$ to $43.4 \%$ of variabilities in the dependent variables of Model-2, Model-3, Model-4, Model 5, Model-6 and Model-7 (Nagelkerke statistics for Model-2= 0.332; Nagelkerke statistics for Model-3=0.378; Nagelkerke statistics for Model-4=0.397; Nagelkerke statistics for Model-5= 0.356; Nagelkerke statistics for Model-6=0.,434; Nagelkerke statistics for Model-7=0.404).

When it comes to the Test of Parallel Lines that are presented in Tab. 1 refers to the assumption of Proportional Odds and show whether the slope coefficients are the same among the categories of the dependent variables of the research models. To not violate this assumption, $p$ values (Sig in Tab. 1.) need to be greater than the 5\% significance level. In this regard, the results from the analyses show that this assumption is satisfied because all $\mathrm{p}$ values in the Test of Parallel Lines regarding all of the research models are greater than the selected significance level $\left(\right.$ Model-1 $=\chi^{2}(6)=4.225, p>0.05$; Model- $2=\chi^{2}(6)=17.133, p>0.05$; Model $-3=\chi^{2}(6)=$ 9.135, $p>0.05$; Model-4= $\chi^{2}(6)=10.369, p>0.05$; Model $-5=\chi^{2}(6)=16.871, p>0.05$; Model $-6=\chi^{2}(6)=$ $12.553, p>0.05$; Model-7 $\left.=\chi^{2}(6)=9.365, p>0.05\right)$. In case of having violation in this assumption, there is a need for using less restricted models such as multinominal logistic regression models (Harrell, 2015). Therefore, the results from those tests confirm the fact that this paper does not violate the assumptions of the ordinal logistic regression test; hence, the results of this test can be interpreted.

Concerning hypotheses testing, the researchers choose a 5\% level of significance to support or fail to support alternative hypotheses. For this reason, $p$ values higher than 5\% significance level make researchers support null hypotheses that assume the nonexistence of positive impacts of the independent variables on the dependent variables. As mentioned above, the independent variables are traditional and technology enabled marketing communication tools, while the dependent variable for each of the research models are Marketing, Logistics, Finance, Human resources, Processes, Management and Supplier-customer relationship, respectively.

Regarding the details of sample characteristics, 392 (48.28\% of the total sample) firms are micro-enterprises that have workers between 0 to 9, 291 firms $(35,84 \%$ of the total sample) might be categorized under the small enterprise's segment that employs workers around 10 to 49 , while other 129 firms ( $15.88 \%$ of the total sample) might be classified as medium-sized enterprises that the number of staff headcount varies between 50 to 249 . Moreover, 393 SMEs (48.4\% of the research sample) were established before the year 2016, while other 419 firms $(51.6 \%$ of the sample) were established after the year 2015. Those firms are located in all geographical regions of Slovakia, including Bratislava, Banská Bystrica, Košice, Nitra, Prešov, Trnava, Trenčín and Žilina regions and perform their businesses activities regarding agriculture, manufacturing, accommodation, retail, financial advertising, accounting, advertising, information technology, automotive, construction, energy, education, financial services, restaurants, real estate and transportation.

With respect to the characteristics of the respondents, 421 survey respondents $(51.85 \%$ of all survey participants) are female, while other 391 respondents are male (49.15\% of all survey respondents). 248 respondents are co-owners (30.54\%), 363 respondents (44.71\%) are company executives, while other 201 respondents $(24.75 \%)$ are owners of those SMEs. 547 survey participants $(67.36 \%$ of all respondents) are less than 30 years old, 132 respondents $(16.26 \%)$ are between 30 to 39 years old, and other 133 survey participants $(16.38 \%)$ are more than 39 years old. Furthermore, 424 of those survey respondents $(52.22 \%$ of all survey participants) have minimum bachelor's degree, and other 388 survey participants (47.78) have lower degrees than bachelor's.

\section{Results}

Tab. 2. indicates the summary of parameter estimates that are gained by Ordinal Logistic Regression analyses. Ordinal regression holds an algorithm including the calculation of a continuous latent variable to indicate the variations in the cut-offs of the dependent variable (Harrell, 2015). A five-point Likert scale is used 
to measure the dependent variables ("1- least significant to 5- most significant"). Therefore, there are 4 cut-offs in the estimated thresholds. For instance, there is a cut-off value between answers of 1 to 2 , and it is indicated as $[$ Marketing $=1]$ in the table. Similarly, [Marketing = 2] represents the cutoff value between 2 to 3 , [Marketing = 3] shows the cutoff value between 3 to 4, while [Marketing =4] reflects a cutoff value between 4 to 5 . Therefore, $[$ Marketing $=1]$ is a predicted cut point on the latent variable, and it is used to show differences from 1-least significant to 2 when the other items and covariates are zero. Those facts are the same for other dependent variables as they are indicated in Tab. 2. and Tab. 3. All those cut-offs are also significant at a 5\% significance level.

According to Tab. 2., the usage of traditional and technology-enabled marketing communication tools positively affects innovations in marketing, logistics, finance and human resources. The reason for that is the usage of traditional and technology-enabled marketing communication tools are significant at a 5\% significance level as they are all indicated under the column of "Sig." in Tab. 2. One unit rise in the usage of marketing communication tools by SMEs will rise its ordered log-odds of having marketing innovations by 0.431 and 0.389 , respectively, for traditional and modern marketing tools, when pegging other variables stable in the research model. When it comes to logistic innovation, if a SME increases the usage of traditional and technology-enabled marketing communication tools by one point, its ordered log-odds of having logistic innovations will increase by 0.509 and 0.189 , respectively, when the other variables are constant in the model.

The results for financial and human resource innovations are quite similar to marketing and logistics innovations. One unit increase in the usage of marketing tools by SMEs will cause increases in its ordered logodds of financial and human resource innovations by 0.506 and 0.494 , respectively, for traditional marketing communication tools and by 0.256 and 0.252 , respectively for modern marketing communication tools. These above-mentioned results also confirm the fact that higher values in the usage of both marketing communication tools are related to more possibilities to be more innovative in marketing, logistics, finance and human resources. When SMEs apply the usage of those communication channels, they become more likely to increase their innovative activities regarding marketing, logistics, finance and human resources. For these reasons, this paper supports H1a, H1b, H2a, H2b, H3a, H3b, H4a and H4b hypotheses.

Tab. 2. The results of ordinal logistic regression tests regarding $1^{\text {st }}, 2^{\text {nd }}, 3^{\text {rd }}$, and $4^{\text {th }}$ models

\begin{tabular}{|c|c|c|c|c|c|c|}
\hline Variable & Estimate & S.E. & Wald & $\mathrm{df}$ & Sig. & $\begin{array}{c}95 \% \text { CI } \\
\text { [Lower Upper] }\end{array}$ \\
\hline \multicolumn{7}{|c|}{ MODEL-1 } \\
\hline Marketing $=1$ & 1.816 & 0.147 & 152.023 & 1 & 0.000 & {$\left[\begin{array}{ll}1.527 & 2.104\end{array}\right]$} \\
\hline Marketing $=2$ & 2.200 & 0.154 & 203.543 & 1 & 0.000 & {$\left[\begin{array}{ll}1.898 & 2.503\end{array}\right]$} \\
\hline Marketing $=3$ & 2.852 & 0.164 & 303.135 & 1 & 0.000 & {$\left[\begin{array}{ll}2.531 & 3.173\end{array}\right]$} \\
\hline Marketing $=4$ & 3.812 & 0.177 & 461.813 & 1 & 0.000 & {$\left[\begin{array}{ll}3.464 & 4.159\end{array}\right]$} \\
\hline Traditional & 0.431 & 0.055 & 60.485 & 1 & 0.000 & {$\left[\begin{array}{ll}0.323 & 0.540\end{array}\right]$} \\
\hline Tech. enabled & 0.389 & 0.050 & 60.240 & 1 & 0.000 & {$\left[\begin{array}{ll}0.291 & 0.488\end{array}\right]$} \\
\hline \multicolumn{7}{|c|}{ MODEL-2 } \\
\hline Logistics $=1$ & 1.844 & 0.154 & 144.217 & 1 & 0.000 & {$\left[\begin{array}{ll}1.543 & 2.145\end{array}\right]$} \\
\hline Logistics $=2$ & 2.458 & 0.162 & 228.980 & 1 & 0.000 & {$\left[\begin{array}{ll}2.140 & 2.777\end{array}\right]$} \\
\hline Logistics $=3$ & 3.339 & 0.175 & 365.926 & 1 & 0.000 & {$\left[\begin{array}{ll}2.997 & 3.681\end{array}\right]$} \\
\hline Logistics $=4$ & 4.664 & 0.208 & 501.659 & 1 & 0.000 & {$\left[\begin{array}{ll}4.256 & 5.073\end{array}\right]$} \\
\hline Traditional & 0.509 & 0.059 & 74.124 & 1 & 0.000 & {$\left[\begin{array}{ll}0.393 & 0.625\end{array}\right]$} \\
\hline Tech. enabled & 0.185 & 0.052 & 12.536 & 1 & 0.000 & {$\left[\begin{array}{ll}0.083 & 0.288\end{array}\right]$} \\
\hline \multicolumn{7}{|c|}{ MODEL-3 } \\
\hline Finance $=1$ & 1.907 & 0.154 & 153.234 & 1 & 0.000 & {$\left[\begin{array}{ll}1.605 & 2.209\end{array}\right]$} \\
\hline Finance $=2$ & 2.524 & 0.164 & 237.564 & 1 & 0.000 & {$\left[\begin{array}{ll}2.203 & 2.845\end{array}\right]$} \\
\hline Finance $=3$ & 3.466 & 0.177 & 384.651 & 1 & 0.000 & {$\left[\begin{array}{ll}3.120 & 3.812\end{array}\right]$} \\
\hline Finance $=4$ & 4.544 & 0.200 & 518.112 & 1 & 0.000 & {$\left[\begin{array}{ll}4.153 & 4.936\end{array}\right]$} \\
\hline Traditional & 0.506 & 0.058 & 75.652 & 1 & 0.000 & {$\left[\begin{array}{ll}0.392 & 0.620\end{array}\right]$} \\
\hline Tech. enabled & 0.256 & 0.052 & 24.565 & 1 & 0.000 & {$\left[\begin{array}{ll}0.154 & 0.357\end{array}\right]$} \\
\hline \multicolumn{7}{|c|}{ MODEL-4 } \\
\hline Hum. Res. = 1 & 1.639 & 0.142 & 133.651 & 1 & 0.000 & {$\left[\begin{array}{ll}1.362 & 1.917\end{array}\right]$} \\
\hline Hum. Res. $=2$ & 2.052 & 0.149 & 190.752 & 1 & 0.000 & {$\left[\begin{array}{ll}1.760 & 2.343\end{array}\right]$} \\
\hline Hum. Res. = 3 & 2.710 & 0.157 & 296.378 & 1 & 0.000 & [2.402 3.019] \\
\hline Hum. Res. = 4 & 3.835 & 0.175 & 480.876 & 1 & 0.000 & {$\left[\begin{array}{ll}3.492 & 4.177\end{array}\right]$} \\
\hline Traditional & 0.494 & 0.056 & 78.573 & 1 & 0.000 & {$\left[\begin{array}{ll}0.384 & 0.603\end{array}\right]$} \\
\hline
\end{tabular}




\begin{tabular}{lllllll} 
Tech. enabled & 0.232 & 0.050 & 21.845 & 1 & $\mathbf{0 . 0 0 0}$ & {$\left[\begin{array}{ll}0.135 & 0.329\end{array}\right]$} \\
\hline \multicolumn{8}{c}{ Source: Own processing. }
\end{tabular}

The results from Ordinal Logistic Regression analyses regarding the usage of traditional and technologyenabled marketing communication tools and their impacts on innovations in process, management and suppliercustomer relationship are presented in Tab. 3. According to Table 3, traditional and technology-enabled marketing communication tools are significant predictors at a 5\% significance level ( $\mathrm{p}$ values are indicated under the column of "Sig." in the table) for process and management innovations. For each one unit increase on both marketing communication tools, there are estimated rises of 0.472 and 0.151 , respectively, in process innovations. Corresponding with management innovations, for every unit increase on both communication tools, there are estimated rises of 0.531 and 0.239 , respectively, in the log odds of falling higher volumes in management innovations. Hence, as scores of traditional and technology enabled marketing communication tools to increase on process and management innovations. There are increased probabilities of falling at higher levels on the process and management innovations.

Table 3. The results of Ordinal Logistic Regression Tests regarding $5^{\text {th }} .6^{\text {th }}$ and 7 th models

\begin{tabular}{|c|c|c|c|c|c|c|}
\hline Variable & Estimate & S.E. & Wald & df & Sig. & $\begin{array}{c}95 \% \text { CI } \\
\text { [Lower Upper] }\end{array}$ \\
\hline \multicolumn{7}{|c|}{ MODEL-5 } \\
\hline Process $=1$ & 1.316 & 0.130 & 102.102 & 1 & 0.000 & {$\left[\begin{array}{ll}1.061 & 1.571\end{array}\right]$} \\
\hline Process $=2$ & 1.645 & 0.135 & 147.899 & 1 & 0.000 & {$\left[\begin{array}{ll}1.380 & 1.910\end{array}\right]$} \\
\hline Process $=3$ & 2.359 & 0.145 & 266.270 & 1 & 0.000 & {$\left[\begin{array}{ll}2.075 & 2.642\end{array}\right]$} \\
\hline Process $=4$ & 3.304 & 0.158 & 434.573 & 1 & 0.000 & {$\left[\begin{array}{ll}2.993 & 3.615\end{array}\right]$} \\
\hline Traditional & 0.472 & 0.054 & 75.720 & 1 & 0.000 & {$\left[\begin{array}{ll}0.366 & 0.579\end{array}\right]$} \\
\hline Tech. enabled & 0.151 & 0.049 & 9.582 & 1 & 0.002 & {$\left[\begin{array}{ll}0.055 & 0.247\end{array}\right]$} \\
\hline \multicolumn{7}{|c|}{ MODEL-6 } \\
\hline Management $=1$ & 1.646 & 0.141 & 136.404 & 1 & 0.000 & {$\left[\begin{array}{ll}1.370 & 1.923\end{array}\right]$} \\
\hline Management $=2$ & 1.950 & 0.146 & 177.363 & 1 & 0.000 & {$\left[\begin{array}{ll}1.663 & 2.236\end{array}\right]$} \\
\hline Management $=3$ & 2.653 & 0.157 & 286.694 & 1 & 0.000 & {$\left[\begin{array}{ll}2.346 & 2.960\end{array}\right]$} \\
\hline Management $=4$ & 3.775 & 0.173 & 476.719 & 1 & 0.000 & {$\left[\begin{array}{ll}3.436 & 4.114\end{array}\right]$} \\
\hline Traditional & 0.531 & 0.055 & 92.180 & 1 & 0.000 & {$\left[\begin{array}{ll}0.422 & 0.639\end{array}\right]$} \\
\hline Tech. enabled & 0.239 & 0.049 & 23.808 & 1 & 0.000 & {$\left[\begin{array}{ll}0.143 & 0.335\end{array}\right]$} \\
\hline \multicolumn{7}{|c|}{ MODEL-7 } \\
\hline Sup.-Cus. R. = 1 & 1.854 & 0.187 & 98.645 & 1 & 0.000 & {$\left[\begin{array}{ll}1.488 & 2.220\end{array}\right]$} \\
\hline Sup.-Cus. R. = 2 & 2.619 & 0.199 & 173.436 & 1 & 0.000 & {$\left[\begin{array}{ll}2.229 & 3.008\end{array}\right]$} \\
\hline Sup.-Cus. R. = 3 & 3.761 & 0.218 & 296.565 & 1 & 0.000 & {$\left[\begin{array}{ll}3.333 & 4.189\end{array}\right]$} \\
\hline Sup.-Cus. R. = 4 & 4.880 & 0.237 & 424.645 & 1 & 0.000 & {$\left[\begin{array}{ll}4.416 & 5.344\end{array}\right]$} \\
\hline Traditional & 1.134 & 0.092 & 150.433 & 1 & 0.000 & {$\left[\begin{array}{ll}0.953 & 1.620\end{array}\right]$} \\
\hline Tech. enabled & 0.059 & 0.080 & 0.542 & 1 & 0.462 & {$\left[\begin{array}{lll}-0.098 & 0.217\end{array}\right]$} \\
\hline
\end{tabular}

Regarding innovations in a supplier-costumer relationship, although the usage of traditional marketing communication tools is a significant predictor. The usage of technology-enabled marketing communication tools is not a significant predictor at a 5\% level of significance (Sig. $p=0.462>0.05$ ). Thus, one unit increase in the traditional marketing tools will cause 1.134 unit estimated rises in the log odds of higher volumes in suppliercustomer relationships while remaining variables are pegged in the research model. For this reason, SMEs using more traditional marketing communication tools become more likely to innovate in process, management and supplier-customer relationships. Those arguments make this paper support H5a, H6a and H7a hypotheses. Similar to the usage of traditional channels, SMEs scoring higher in the usage of modern marketing tools are more likely to indicate more innovations in process and management. For this reason, this paper also supports the H5b and H6b hypotheses. However, since the paper does not find a significant result for the effects of the usage of technology-enabled marketing tools on innovations in supplier-customer relationships, this paper fails to support the $\mathrm{H} 7 \mathrm{~b}$ hypotheses.

\section{Discussion}

The results of this paper confirm the fact that the usage of marketing communication tools by SMEs positively affects their marketing innovations. This result is compatible with the findings of Amoah and Jibril 
(2020). Gabrielli and Balboni (2015) and Pisicchio and Toaldo (2020) since those researchers also substantiate the positive impacts of marketing communication tools on marketing innovation. Regarding innovations in logistics. This paper also proves that the usage of marketing communication tools positively influences logistic innovation. Hence, this result is consistent with the results of Chakraborty et al. (2016). Cabiddu et al. (2020) and (Milichovský, 2017) because those studies also bear out the positive relationship between the usage of marketing tools and innovations in logistic activities of firms.

Corresponding to innovation in finance and the usage of marketing communication tools, this paper confirms the positive impacts of the usage of those channels on innovations in finance. In this regard, this paper finds a similar result with Ratnakaram et al. (2021) since those researchers also mention the benefits that marketing communication tools provide for the financial purposes of businesses. With respect to human resources and marketing tools, this paper validates the positive effects of the usage of marketing communication tools on innovations in the human resource operations of firms. For this reason, this result of the paper is parallel with the studies of Martinez and Dolores (2018) and Laužikas and Miliūtè (2020). The reason for that is those researchers also verify the positive influences of marketing communication tools on innovations in human resource management.

Concerning process innovations, this paper also vindicates the positive impacts of the usage of marketing communication tools on process innovations. Thus, this result is in line with the findings of Ahmad and Salleh (2019), Pisicchio and Toaldo (2020), Wardati and Mahendrawathi (2019), Seiler et al. (2020), Amoah et al. (2021), Zaušková et al. (2015) and Falcones and Castilla (2020). since those scholars reveal the contributions of marketing communication tools on the innovations of various processes of business operations. When it comes to managerial innovations, the results of this paper indicate that both marketing tools stimulate the innovative posture of firms in management. This result makes this paper have compatible results with the studies of Hultman et al. (2011), Ližbetinová et al. (2019) and Laužikas and Miliūtè (2020) since these papers claim the advantages that the marketing communication tools create for managerial purposes of businesses.

With respect to the positive impacts of the usage of marketing communication tools on the suppliercostumer relationship, the results of this paper differ depending on the type of those tools. While the usage of traditional marketing communication channels makes positive contributions to the relationships between firms and their suppliers-customers, this paper does not find any positive statistical effects of the usage of technology enabled marketing tools on firms' supplier-customer relationships. Thus, this result makes this paper object to the findings of Pisicchio and Toaldo (2020). Turan and Kara (2018). Calefato et al. (2015) and Amoah et al. (2021) since these researchers advocate the positive impacts of marketing communication tools on the suppliercustomer relationships of firms.

The location of businesses might also determine the usage of marketing communication tools (FossoWamba \& Carter, 2014). For instance, around $47 \%$ of the firms that are analyzed in this research are from the rural or semi-rural areas of Slovakia. According to Lazikova et al. (2018). except Bratislava region. other regions of Slovakia are categorized under the rural or semi-rural areas. Since companies, suppliers, and customers have dispersed settlements in those kinds of areas, many firms might have moved their communication strategies from traditional marketing tools such as personal sales, exhibitions or trade fairs to technology-enabled marketing tools. In this regard, moving on to those technologies enabled channels might have made SMEs loosen their relationships with their customers and suppliers. But in the Bratislava regions, where settlements are closer, firms might have had used more traditional approaches to communicate with their suppliers and customers. This fact might be the reason why the usage of traditional communication tools positively affects the suppliercustomer relationships of businesses.

Moreover, according to OECD (2018), there is a huge regional gap in Slovakia regarding the GDP per capita of the Bratislava Region and other areas. Although traditional marketing communication tools are more costly than technology-enabled marketing communication tools, since the majority of SMEs that are analyzed in this paper are located in the Bratislava region, they might have afforded those expenses to create more close relationships with their customers and suppliers. But, since other SMEs come from low-income regions, they might have had used less costly options of technology enabled marketing tools that cause businesses to keep their distance with their suppliers and customers.

Covid-19 pandemic might be another reason why technology enabled marketing tools do not improve the relationship between firms and their suppliers-customers. This is because the data collection process of this research was completed in January 2021, when the pandemic was still in existence. Thus, governments made some regulations to keep social distance between individuals. Some activities regarding traditional marketing communication such as personal selling and exhibitions that cause the face to face interactions became reduced due to the rules that were set by the governments. Thus, similar to other countries. The slovakian government also created some barriers to limit individuals' close interactions, and firms had to move some of their marketing activities via technology-enabled marketing tools such as social media platforms that enabled distant relationships and loosened the close relations. This fact might be an argument to support why this paper does not find any significant positive impacts of technology-enabled marketing tools on a supplier-customer relationship. 
Moreover, the time that marketing staff spends for the usage of marketing communication tools might be another reason to explain the nonexistence of positive influences of modern marketing tools on suppliercustomer relationships. Traditional marketing communication tools exhibitions. Fairs personal selling make marketing staffs of businesses spend more hours for their suppliers and customers, and this fact increases closer interactions between parties. Moreover, the most popular marketing communication tools that enable closer personal contact with customers are participation in fairs, trade shows, workshops (Adamska, 2020), official/unofficial meetings, phone calls, doors open days and working with key clients (Bobalo, 2018) that make businesses to spend more time with their customers and suppliers. But when it comes to technology-enabled marketing communication tools, they enable businesses to save their time due to having a lack of face to face interactions. Therefore, since parties spend less time with each other, the relationship that they have might be weaker compared with traditional channels. Hence, although technology enabled marketing tools make people save their time, it might create negative consequences such as loosening the relationship between the sides of communications.

Another reason why the usage of technology enabled marketing tools does not make positive contributions to the supplier-customer relationship of businesses might stem from the effective usage of those channels. For instance, although firms use social media platforms or other channels of technology-enabled marketing tools, workers who are responsible for those operations might not consider the feedback of their customers. Even those workers see comments of their customers; they might not have the willingness or capabilities to solve issues and satisfy the needs of their customers. In this regard, the brand image of companies gets worse from the perspective of their customers. Furthermore, workers of SMEs might not have enough competencies and experiences regarding the effective usage of those channels.

To cope with those obstacles, firms need to take quick actions to find solutions for their lack of skilled workers. In this regard, they need to make investments in their human resources and provide some education and training for their workers to increase their abilities and experiences. When providing such training, SMEs can receive some support from marketing agencies or universities that have experts in this field. Another important factor that increases the success of SMEs regarding their marketing purposes is to have intelligent, innovative and informed owners or executives. Therefore, training or other educational activities should not be provided only for the workers but also for company executives. Since those activities might be costly for SMEs, financial support of the governments and the collaboration of governments with marketing professionals and universities are a prerequisite for the marketing performance of SMEs. It should be borne in mind that improvements in businesses can also be reflected in other areas of economic life (Bilan et al., 2017; Gavurova et al., 2020b; Ivankova et al., 2021)

\section{Conclusions}

The development in technologies and the existence of new communication channels have done businesses to take quick actions for their customers' demands. To satisfy their customers' needs, many SMEs use those developed marketing communication tools that provide less costly but more innovative solutions for their functional business areas. Since SMEs usually experience problems in financing, the usage of those tools might not only enable them to compete with their rivals but also increase their innovative abilities in all organizational processes. In this regard, this paper investigates whether the usage of traditional and technology-enabled marketing communication tools does affect innovative actions in those functional business areas or not. The researchers have collected data by employing an online internet-mediated questionnaire to fulfil this objective. 812 randomly selected SMEs in Slovakia have fulfilled the questionnaires, while the respondents are company executives. The researchers also apply Ordinal Logistic Regression analyses via SPSS Statistical Software to find the impacts of those communication tools on various functional areas of businesses such as marketing, logistics, finance, human resources, processes, management and supplier-customer relationship.

The results of this paper indicate that traditional marketing communication tools positively affect innovations in all of the above mentioned functional areas of businesses. Concerning the technology enabled marketing tools and their impacts on those areas, this paper finds different results. Although technology enabled marketing tools do not have any significant impacts on innovations in the supplier-customer relationship of businesses, those tools do positively affect other areas, including marketing, logistics, finance, human resources, processes and management. The nonexistence of significant impacts of technology enabled marketing tools on the supplier-customer relationship might be related to the location of SMEs income gap in different geographical regions. Negative outcomes of Covid-19 pandemic, lack of time of marketing staff to focus on those channels, the existence of lack of experienced and talented workers and the workers' and executives ineffective usage of those tools. All the recommendations resulting from this study are also applicable to companies operating in the mining industry. In this way, the main findings provide valuable perspectives and inspiration for the mining industry. 
To cope with those problems, SMEs need to focus on some strategies that make their human capital improve. Those strategies might include providing training and educational activities of some marketing experts for their staff. To bear the costs of those activities, governments might give some incentives and subsidies for SMEs and might make SMEs be more motivated when performing their marketing strategies. Since SMEs have crucial roles in developing economies, the financial support of governments for SMEs might make countries reach better volumes from economic indexes.

As already mentioned elsewhere in this paper, this paper is a comprehensive study and has a wide scope to analyze both marketing communication tools and functional areas of businesses. For these reasons, this paper differs from other studies on this specific topic and make positive contributions to the related literature. On the other hand, some limitations are in existence in this paper. For instance, this paper only analyzes the segment of SMEs, and those SMEs are located in Slovakia. For this reason, new studies can also analyze larger enterprises and SMEs from other countries to compare and find differences between the usage of marketing communication tools by enterprises depending on their size and country. Further studies might also consider Firm-individual characteristics and other operational areas of businesses to find some other details regarding the usage of those channels and differences in innovations of functional business areas.

\section{References}

Adamska, M. (2020). Practical application of forms and tools of marketing communication in the sme sector. Economics and Management, 23(2), 193-209.

Ahmad, A., \& Salleh, S. M. (2019). Brand related capabilities and the process of integrated marketing communications (IMC): A resource based view (rbv). Journal of Contemporary Research in Social Sciences, 1, 136-150. https://doi.org/10.33094/26410249.2019.16.136.150

Amirkhanpour, M., Vrontis, D., \& Thrassou, A. (2014). Mobile marketing: a contemporary strategic perspective. International Journal of Technology Marketing $5, \quad 9(3), \quad 252-269$. https://doi.org/10.1504/IJTMKT.2014.063855

Amoah, J., Belás, J., Khan, K. A., \& Metzker, Z. (2021). Antecedents of sustainable smes in the social media space: a partial least square-structural equation modeling (pls-sem) approach. Management \& Marketing. Challenges for the Knowledge Society, 16(1), 26-46. https://doi.org/10.2478/mmcks-2021-0003.

Amoah, J., \& Jibril, A. B. (2020). Inhibitors of social media as an innovative tool for advertising and MARKETING communication: Evidence from SMEs in a developing country. Innovative Marketing. 16(4), 164-179. https://doi.org/10.21511/im.16(4).2020.15

Appiah, M. K., Possumah, B. Y., Ahmat, N. \& Sanusi, N. A. (2019). Small and medium enterprise's internal resources and investment decisions in Ghana: The resource-based approach. Economics and Sociology, 12(3), 37-53. https://doi.org/10.14254/2071-789X.2019/12-3/3

Belas, J., Gavurova, B., Cepel, M., \& Kubak, M. (2020). Evaluation of economic potential of business environment development by comparing sector differences: Perspective of SMEs in the Czech Republic and Slovakia. Oeconomia Copernicana, 11(1), 135-159. https://doi.org/10.24136/oc.2020.006

Bilan, Y., Gavurova, B., Stanislaw, G., \& Tkacova, A. (2017). The Composite Coincident Indicator (CCI) for business cycles. Acta Polytechnica Hungarica, 14(7), 71-90. https://doi.org/10.12700/aph.14.7.2017.7.5

Bobalo, O. (2018). Future of offline marketing ahead of the rapid development of online marketing. Baltic Journal of Economic Studies, 4(3), 1-7. https://doi.org/10.30525/2256-0742/2018-4-3-1-7

Cabiddu, F., Moi, L., Jaaskelainen, P., Pilař, L., Pitrová, J., \& Petkov, R. (2020). Where to invest in online marketing education in micro and small enterprises. In 17th International Conference Efficiency and Responsibility in Education 2020, 46-53.

Calefato, F., Lanubile, F., \& Novielli, N. (2015). The role of social media in affective trust building in customersupplier relationships. Electronic Commerce Research, 15(4), 453-482. https://doi.org/10.1007/s10660015-9194-3

Cant, M. C., \& Wiid, J. A. (2016). The use of traditional marketing tools by SMEs in an emerging economy: a South African perspective. Problems and perspectives in management, 14(1), 64-70.

Chakraborty, R., Lee, J., Bagchi-Sen, S., Upadhyaya, S. \& Raghav Rao, H. (2016). Online shopping intention in the context of data breach in online retail stores: An examination of older and younger adults. Decision Support Systems, 83, 47-56. https://doi.org/10.1016/j.dss.2015.12.007

Falcones, W. A., \& Castilla, J. I. M. (2020). Factors affecting the implementation of innovation strategies in a dynamic environment: case SMES of the tourism sector in Ecuador. GCG: revista de globalización, competitividad y gobernabilidad, 14(2), 50-68.

Fosso-Wamba, S., \& Carter, L. (2014). Social media tools adoption and use by SMES: An empirical study. Journal of Organizational and End User Computing, 26(2), 1-17. https://doi.org/10.4018/978-1-46668614-4.ch035 
Gabrielli, V., \& Balboni, B. (2010). SME practice towards integrated marketing communications. Marketing Intelligence \& Planning, 28 (3), 275-290. https://doi.org/10.1108/02634501011041426.

Gavurova, B., Belas, J., Bilan, Y., \& Horak, J. (2020a). Study of legislative and administrative obstacles to SMEs business in the Czech Republic and Slovakia. Oeconomia Copernicana, 11(4), 689-719. https://doi.org/10.24136/oc.2020.028

Gavurova, B., Ivankova, V., Rigelsky, M., \& Privarova, M. (2020b). Relations between tourism spending and global competitiveness: An empirical study in developed OECD countries. Journal of Tourism and Services, 11(21), 38-54. https://doi.org/10.29036/jots.v11i21.175

Harrell, F. E. (2015). Regression Modeling Strategies: With Applications to Linear Models, Logistic and Ordinal Regression, and Survival Analysis, 2nd ed. Springer.

Hultman, M., Katsikeas, C. S., \& Robson, M. J. (2011). Export promotion strategy and performance: the role of international experience. Journal of international marketing, 19(4), 17-39. https://doi.org/10.1509/jim.11.0022

Ibrahim, I., Ismail, A.F.-M.F., Amer, A., \& Jani, S.H.M. (2019). The effectiveness of mass marketing communication as a digital logistics tools in promoting a new online public service platform. International Journal of Supply Chain Management 8(4), 177-185

Indrupati, J., \& Henari, T. (2012). Entrepreneurial success, using online social networking: evaluation. Education, Business and Society: Contemporary Middle Eastern Issues, 5(1), 47-62. https://doi.org/10.1108/17537981211225853

Ivankova, V., Gavurova, B., Bačík, R., \& Rigelský, M. (2021). Relationships between road transport infrastructure and tourism spending: A development approach in European OECD countries. Entrepreneurship and Sustainability Issues, 9(2), 535-551. https://doi.org/10.9770/jesi.2021.9.2(35)

Jakhiya, M., Bishnoi, M., \& Purohit, H., (2020). Emergence and Growth of Mobile Money in Modern India: A Study on the Effect of Mobile Money. Advances in Science and Engineering Technology International Conferences (ASET), 1-10.

Jokonya, O., \& Mugisha, C. (2019). Factors influencing retail SMEs adoption of social media for digital marketing. In ECSM 2019 6th European Conference on Social Media (p. 145). Academic Conferences and publishing limited.

Kakushadze, Z. \& Liew, J. K. (2020). Coronavirus: Case for Digital Money? World Economics 21(1), 177-190. arXiv:2005.10154 [q-fin.GN]

Kizim, A. A., Pogosovna Kajfedzhan, D., Gayduk, V. I., Sekerin, V. D., \& Gorokhova, A. E. (2019). Specifics of choosing the modern communication technologies in Marketing and Logistics Based on innovative approaches. Dilemas Contemporáneos: Educación, Política y Valores, 7(1).

Korzeb, Z., \& Niedziółka, P. (2020). Resistance of commercial banks to the crisis caused by the COVID-19 pandemic: the case of Poland. Equilibrium. Quarterly Journal of Economics and Economic Policy, 15(2), 205-234. https://doi.org/10.24136/eq.2020.010.

Kotler, P.\& Keller, K.L. (2009). Marketing Management, 13th edition, Pearson, p. 816, ISBN-13: 9780136009986.

Laužikas, M.,\& Miliūtè, A. (2020). Impacts of modern technologies on sustainable communication of civil service organizations. Entrepreneurship and Sustainability Issues, 7(3), 2494-2509. http://doi.org/10.9770/jesi.2020.7.3(69)

Lazíková, J., Bandlerová, A., Roháčiková, O., Schwarcz, P., \& Rumanovská, L. (2018). Regional Disparities of Small and Medium Enterprises in Slovakia. Acta Polytechnica Hungarica, 15(8), 227-246.

Lee, Y. C. (2017). Corporate sustainable development and marketing communications on social media: Fortune 500 enterprises. Business Strategy and the Environment, 26(5), 569-583.

Leopold, H. (2019). Social media and corporate innovation management-Eight rules to form an innovative organisation. e \& i Elektrotechnik und Informationstechnik, 136(3), 241-253.

Ližbetinová, L., Štarchoň, P., Lorincová, S., Weberová, D., \& Průša, P. (2019). Application of cluster analysis in marketing communications in small and medium-sized enterprises: An empirical study in the Slovak Republic. Sustainability, 11(8), 2302.

Mabrouk, N. B. (2020). Analysis of Critical Factors Influencing the Supply Chain Performance of Small and Medium Enterprises. Journal of Advanced Manufacturing Systems, 1-17.

Martinez G., \& Dolores, M. (2018). Digital content for the training of human capital at work, through the REA Platform. Etic Net-Revista Cientifica Electronica De Educacion Y Comunicacion En La Sociedad Del Conocimiento, 18(2), 351-364.

Milichovský, F. (2017). An impact of reverse logistics activities on marketing communication. Acta Universitatis Agriculturae et Silviculturae Mendelianae Brunensis, 65(2), 669-678.

Nicola, M., Alsafi, Z., Sohrabi, C., Kerwan, A., Al-Jabir, A., Iosifidis, C., Agha, M. \& Agha, R. (2020). The socio-economic implications of the coronavirus pandemic (COVID-19): A review. International Journal of Surgery, 78, 185-193. 
OECD, (2018). Regions and Cities at a Glance 2018 - Slovak Republic. Retrieved from https://www.oecd.org/cfe/SLOVAK-REPUBLIC-Regions-and-Cities-2018.pdf

Pantano, E., Pizzi, G., Scarpi, D. \& Dennis, C. (2020). Competing during a pandemic? Retailers' ups and downs during the COVID-19 outbreak. Journal of Business Research, 116, 209-213.

Petersen, J.A., McAlister, L., Reibstein, D.J., Winer, R.S,; Kumar, V.,\& Atkinson, G. (2009). Choosing the right metrics to maximize profitability and shareholder value. Journal of Retailing, 85(1), 95-111. https://doi.org/10.1016/j.jretai.2008.11.004

Pisicchio, A. C., \& Toaldo, A. M. M. (2020). Integrated marketing communication in hospitality SMEs: analyzing the antecedent role of innovation orientation and the effect on market performance. Journal of Marketing Communications, 1-20. https://doi.org/10.1080/13527266.2020.1759121

Porcu, L., S. Del Barrio-García, J. M. Alcántara-Pilar, E. Crespo-Almendros. (2017). Do adhocracy and market cultures facilitate firm-wide integrated marketing communication? International Journal of Advertising 36 (1): 121-141. https://doi.org/10.1080/02650487.2016.1185207.

Ratnakaram, S., Chakravaram, V., Vihari, N. S., \& Rao, G. V. (2021). Emerging Trends in the Marketing of Financially Engineered Insurance Products. In ICT Systems and Sustainability, 675-684, Springer, Singapore. . https://doi.org/10.1007/978-981-15-8289-9_65

Seiler, A., Papanagnou, C., \& Scarf, P. (2020). On the relationship between financial performance and position of businesses in supply chain networks. International Journal of Production Economics, 227, 107690. https://doi.org/10.1016/j.ijpe.2020.107690

Taiminen, H. M., \& Karjaluoto, H. (2015). The usage of digital marketing channels in SMEs. Journal of Small Business and Enterprise Development, 22(4), 633-651. https://doi.org/10.1108/JSBED-05-2013-0073

Turan, M., \& Kara, A. (2018). Online social media usage behavior of entrepreneurs in an emerging market. Journal of Research in Marketing and Entrepreneurship. . https://doi.org/10.1108/JRME-09-2016-0034

Wahyuni, F., \& Aprilia, M. P. (2019). The process of innovation adoption by the use of e-commerce marketing application: Case Study on Indonesia Small Medium Enterprise Community. In 2019 IEEE 4th International Conference on Computer and Communication Systems, 751-756. https://doi.org/10.1109/CCOMS.2019.8821679.

Wardati, N. K., \& Mahendrawathi, E. R. (2019). The impact of social media usage on the sales process in small and medium enterprises (SMEs): A systematic literature review. Procedia Computer Science, 161, 976983. https://doi.org/10.1016/j.procs.2019.11.207

Zaušková, A. \& Grib, L. (2014). Marketing communication of eco-innovations and their impact on regional development. In Conference Proceedings. Trnava: FMK UCM in Trnava, 483.

Zaušková, A., Bezáková, Z., \& Grib, L. (2015). Marketing communication in eco-innovation process. Procedia Economics and Finance, 34, 670-675. https://doi.org/10.1016/S2212-5671(15)01684-6

Zontek, Z. (2016). The role of human resources in enhancing innovation in tourism enterprises. Managing Global Transitions, 14 (1): 55-73. 